\title{
Contracts to Communities: \\ A Processual Model of Organizational Virtue
}

\section{Pursey P.M.A.R. Heugens, Muel Kaptein and J. van Oosterhout}

\begin{tabular}{|l|l|}
\hline \multicolumn{2}{|l|}{ ERIM REPORT SERIES RESEARCH IN MANAGEMENT } \\
\hline ERIM Report Series reference number & ERS-2007-023-ORG \\
\hline Publication & April 2007 \\
\hline Number of pages & 40 \\
\hline Persistent paper URL & \\
\hline Email address corresponding author & pheugens@rsm.nl \\
\hline Address & Erasmus Research Institute of Management (ERIM) \\
& RSM Erasmus University / Erasmus School of Economics \\
& Erasmus Universiteit Rotterdam \\
& P.O.Box 1738 \\
& 3000 DR Rotterdam, The Netherlands \\
& Phone: $\quad+31104081182$ \\
& Fax: $\quad+31104089640$ \\
& Email: info@erim.eur.nl \\
& Internet: $\quad$ www.erim.eur.nl \\
\hline
\end{tabular}

Bibliographic data and classifications of all the ERIM reports are also available on the ERIM website: www.erim.eur.n 


\section{ERASMUS RESEARCH INSTITUTE OF MANAGEMENT}

\section{REPORT SERIES}

\section{RESEARCH IN MANAGEMENT}

\begin{tabular}{|l|l|}
\hline ABSTRACT AND KEYWORDS \\
\hline Abstract & $\begin{array}{l}\text { In the face of systemic challenges to corporate legitimacy, scholars and managers alike have } \\
\text { been rethinking traditional answers to the question: What does it take to be a good company? } \\
\text { We approach this question in two novel ways. We offer a normative answer, grounded in virtue } \\
\text { ethics, by introducing a threefold typology of organizational forms. The moral goodness of each } \\
\text { form depends on the congruence between its purpose and virtues. But we also offer a positive } \\
\text { answer in the form of a processual model which traces corporate goodness to its empirical } \\
\text { antecedents and consequences. The model defies a view of organizations as innately good or } \\
\text { evil, but rather portrays virtue as the sediment of a value infusion process. We predict that if } \\
\text { managers succeed in establishing in their organizations the kind of virtues necessary to support } \\
\text { collective moral agency, they can expect to reap gains like enhanced effectiveness and } \\
\text { legitimacy. However, when they neglect their moral responsibilities, the result will likely be } \\
\text { organizational demise. }\end{array}$ \\
\hline Free Keywords & $\begin{array}{l}\text { Business ethics, Positive theorizing, Normative theorizing, Virtue ethics, Stakeholder theory, } \\
\text { Corporate performance, Organizational goodness }\end{array}$ \\
\hline Availability & $\begin{array}{l}\text { The ERIM Report Series is distributed through the following platforms: } \\
\text { Academic Repository at Erasmus University (DEAR), DEAR ERIM Series Portal } \\
\text { Social Science Research Network (SSRN), SSRN ERIM Series Webpage } \\
\text { Research Papers in Economics (REPEC), REPEC ERIM Series Webpage }\end{array}$ \\
\hline Classifications & $\begin{array}{l}\text { The electronic versions of the papers in the ERIM report Series contain bibliographic metadata } \\
\text { by the following classification systems: } \\
\text { Library of Congress Classification, (LCC) LCC Webpage } \\
\text { Journal of Economic Literature, (JEL), JEL Webpage } \\
\text { ACM Computing Classification System CCS Webpage } \\
\text { Inspec Classification scheme (ICS), ICS Webpage }\end{array}$ \\
\hline
\end{tabular}


CONTRACTS TO COMMUNITIES: A PROCESSUAL MODEL OF

ORGANIZATIONAL VIRTUE

\author{
Pursey P. M. A. R. Heugens
}

Muel Kaptein

J. (Hans) van Oosterhout

Department of Business-Society Management

Rotterdam School of Management

Erasmus University Rotterdam

P.O. Box 1738

3000 DR Rotterdam

The Netherlands

pheugens@rsm.nl

mkaptein@rsm.nl

joosterhout@rsm.nl 


\title{
CONTRACTS TO COMMUNITIES: A PROCESSUAL MODEL OF \\ ORGANIZATIONAL VIRTUE
}

\begin{abstract}
In the face of systemic challenges to corporate legitimacy, scholars and managers alike have been rethinking traditional answers to the question: What does it take to be a good company? We approach this question in two novel ways. We offer a normative answer, grounded in virtue ethics, by introducing a threefold typology of organizational forms. The moral goodness of each form depends on the congruence between its purpose and virtues. But we also offer a positive answer in the form of a processual model which traces corporate goodness to its empirical antecedents and consequences. The model defies a view of organizations as innately good or evil, but rather portrays virtue as the sediment of a value infusion process. We predict that if managers succeed in establishing in their organizations the kind of virtues necessary to support collective moral agency, they can expect to reap gains like enhanced effectiveness and legitimacy. However, when they neglect their moral responsibilities, the result will likely be organizational demise.
\end{abstract}




\section{POSITIVE AND NORMATIVE VIEWS OF 'GOODNESS'}

Since the collapse of Enron in 2001, a wave of scandals has ravaged the corporate world and fundamentally shaken investors' confidence in financial markets. Some of the implicated companies include Tyco (U.S.), WorldCom (U.S.), Sumitomo Corp. (Japan), Parmalat (Italy), and Ahold (the Netherlands). That the recent scandals eroded billions of dollars of shareholder value, and that corporate representatives have been imprisoned for white collar fraud is nothing new. What is both novel and deeply disturbing about the latest incidents is that they happened to those of whom we least expected it. They did not happen to notorious laggards, but to companies that outperformed virtually all others in their respective industries. They did not happen on the watch of CEOs with prior stains and smears, but in companies led by the best and brightest representatives of the managerial profession. They also did not hit companies lacking innovative potential, but instead those with the smartest business models. These scandals thus force us to rethink our traditional answers to the question: What does it take to be a good company?

Many have proposed that the answer to this question must be grounded in (business) ethics, as the scandals have illustrated the bankruptcy of amoral business models that have gone too far in relaxing moral constraints in the pursuit of profit. Especially virtue ethics is proposed as a promising foundation for new definitions of corporate goodness (Heugens et al., 2006; Moore, 2005; Solomon, 2003; Weaver, 2006), because of the perspective's superior fit with the field of management studies. This fit manifests itself in three ways. First, virtue ethics is an ethics of aspiration, as it reflects on actors' ambitions to excel in what they were meant to do (MacIntyre, 1985; Moore and Beadle, 2006; Pence, 1991). This coheres with a field that teaches managers to pursue objectives derived from the corporate mission. Second, virtues have historically been defined as skills (Bloomfield, 2000). In the Gorgias, one of the 
early Platonic dialogues, Socrates argues that the moral virtues of courage, temperance, wisdom, and justice are skills, which are to be learned in ways similar to how one would master the skills of medicine and navigation. This view is congruent with a portrayal of organizations as repositories of skills and capabilities. Third, virtue ethics is moderately communitarian (Etzioni, 1996), in that it recognizes the virtues of common pursuit (Sherman, 1993) and acknowledges that collective actors can themselves be the bearer of virtues (Tomasi, 1991), without thereby denying the responsibilities of individual human beings. This view is amicable to a field in which it is argued that theories of organizations have to be micro founded "in the sense that they must involve, or at least be consistent with a story of what agents do and why they do it" (Dosi 1997: 1531). In sum, in terms of its congruence with the field of management studies, virtue ethics appears to be superior to other ethical theories, especially to those that are staunchly individualistic (like utilitarianism) or that forbid certain means for the pursuit of economic ends (like Kantian ethics).

In spite of its promise, virtue ethics' impact on the field of management studies is rather modest. Granted, it is one of the 'centers of gravity' in business ethics (Heugens et al., 2006), but even business ethicists rarely explore how their conceptions of corporate goodness touch upon the type of phenomena that matter most to management scholars, such as organizational legitimacy and survival. This is a worrisome conclusion, because the question concerning corporate goodness demands a double answer. It obviously demands a normative answer, as one of the interpretations of "goodness" is "moral goodness." Such an answer revolves around the discovery of the moral goodness of certain organizational types, and this has long been the primary occupation of virtue ethicists (e.g., Moore, 2005; Moore and Beadle, 2006; Solomon, 2004; Weaver, 2006). But it also demands a positive answer, one that traces virtues to their antecedents and connects them with meaningful outcomes. It is here that business ethicists usually remain silent. We therefore aspire to say something more about the 
qualities of virtue ethics as a normative and positive theory of organizational goodness. This ambition can only be realized by integrating virtue theory with management theories. The 'double yield' of our integrative efforts includes a normative view of virtuous organizations, but also a positive view of the process by which organizational virtue becomes institutionalized and converted into tangible outcomes.

\section{NORMATIVELY ‘GOOD’ ORGANIZATIONS: A TYPOLOGY}

It is impossible to understand virtue theory without exploring its intellectual roots. These can be traced to Platonic works like the Gorgias, the Meno, the Philebus, and the Republic and, most importantly, to Aristotle's Nicomachean Ethics (NE). The core premises of virtue ethics can easily be summed up. Virtue ethics is often described as the ethics of character (Moore, 2005), and the central question it seeks to answer is therefore not "which moral laws must be obeyed under all circumstances?" (Kantian ethics) or "how can we bring about the greatest happiness for the greatest number?" (utilitarian ethics), but "who should I aspire to be as a person?" or "what should we aspire to be as an organization?" The objective of the approach is not to write the decision-algorithm for the behaviorally perfect ethical robot (Pence, 1991), but to understand how the character of the acting individual or organization is shaped by its social context, which is partially self-enacted through prior choices (MacIntyre, 1985).

Such a contextualized ethics leaves little room for moral universals. Especially in business, "audacity becomes the merchant but not the banker, creativity the designer but not the accountant, and impartiality the mediator but not the attorney" (Heugens et al., 2006: p. 401). So what to take as an Archimedean point from which to deduce the relevant virtues for a given organization? The answer is provided by Aristotle, who observes that "Every art and

every investigation, and similarly every action and pursuit, is considered to aim at some 
good" (NE 1094a). ${ }^{1}$ Each individual is born or socialized (and each organization founded) for the pursuit of a specific goal or telos. This telos holds the key to deciphering the relevant set of virtues an actor must possess. Specifically, desirable virtues are those allowing an actor to excel in "any coherent and complex form of socially established cooperative human activity" (MacIntyre, 1985: 187) to which it is called by tradition, duty, or ambition. Relevant virtues are therefore determined by the goals an actor means to pursue.

So what does it take to be a good company? A contextualized ethics like virtue theory cannot produce a universal answer to this question, since the relevant set of virtues for a given organization is determined by its telos. But we ought not commit to ethical relativism, which holds that there can be no normative common ground across organizations at all, since virtues are always specific to individual cases. Instead, we will develop a Mertonian-style theory of the middle range, a new representative of a broader class of "theories that lie between the minor but necessary working hypotheses that evolve in abundance during day-to-day research; and the all-inclusive systematic efforts to develop a unified theory that will explain all the observed uniformities of social behavior, social organization and social change" (Merton, 1968: 39). Specifically, we develop a three-pronged typology of organizations, grouped in terms of their teloi. Our objective is to create sufficient intra-type homogeneity (to escape relativism), complemented by adequate inter-type heterogeneity (to avoid universalism), in order to enable purposeful reflection on class-specific ethical virtues. The three organizational types we discuss here are: (1) the nexus-of-contracts organization, (2) the utilitarian organization, and (3) the moral community. ${ }^{2}$

\section{The Nexus-of-Contracts Organization}

The nexus-of-contracts organization was first discussed by Alchian and Demsetz (1972) and Jensen and Meckling (1976). It is best seen as a legal entity that serves as a focal point for a 
complex set of written and unwritten contracts amongst disparate organizational participants. The marvel of this organizational type is that it supplants the multilateral contracts between the many parties one typically finds in markets with a system in which the interactions between cooperating agents are structured as unilateral contracts with the legal entity. According to Zingales (2000), the nexus-of-contracts firm does not really exist as a separate actor, but is instead a largely fictitious creature, which serves as a convenient "shorthand notation" for the underlying set of contracts. This view closely matches Alchian and Demsetz' (1972) original conceptualization, who observed that the firm:

\footnotetext{
"has no power of fiat, no authority, no disciplinary action any different in the slightest degree from ordinary market contracting between any two people (...) [The firm] can fire or sue, just as I can fire my grocer by stopping purchases from him, or sue him for delivering faulty products" (p. 777).
}

According to this view, the behavior of the legally fictitious organization represents the equilibrium-seeking behavior of a complex contractual system, through which dissimilarly endowed and motivated contractual agents clear their differences. Jensen and Meckling (1976) offer a slightly more socialized view of the nexus-of-contracts organization. In their interpretation the organization remains a vehicle by which individuals can pursue their private interests, and its raison d'être still is that it saves transaction costs, such that individuals can reach their goals with less effort or expense. But it is also a regulatory institution that codifies a number of critical 'rules of the game' (Jensen, 1983: 326). It specifies (a) a performance evaluation system and (b) a reward system, and (c) it allocates decision rights. These systems facilitate cooperative interactions between organizational participants by preventing an opportunism-prone minority to pursue its self-interest 'with guile' at the expense of the collective (cf. Williamson, 1985). Nexus-of-contracts organizations are thus more than legal 
fictions, because the repositories of decision rules they harbor for policing opportunists are not easily found in markets (Heugens, 2005).

Since individuals join a nexus-of-contracts organization to advance their own good, the teloi of such organizations revolve around individual utility maximization, and the locus of these teloi are the individual members (see Table 1). This notion is consistent with the view that nexus-of-contracts organizations can simultaneously serve many disparate interests by serving as an ingenious clearing system, allowing individuals to merely focus on the material interests they have in common, and declare all other features of their trading partners irrelevant for the exchange at hand (Heugens and van Oosterhout, 2002). Nexus-of-contracts organizations are thus a-moral creatures. This does not imply that morality has no place in such organizations, but to the extent that they harbor virtues, these are located at the level of the individual organizational participants. In other words, corporate goodness in this breed of organizations is not a form of collective goodness, but merely the sum of virtues contained in the corporation's members. Corporate goodness is thus critically dependent on what comes to participants' minds about being good to others and being good to themselves. This "good" can be virtue. Members' repeated interactions with other organizational participants give salience to the notion of mutual identity, and thus urge them to give up the agent neutrality that is foundational to utilitarian or Kantian ethics (van Oosterhout et al., 2006). But the scope of these virtues is limited. As Sherman (1993: 278) puts it: "Treating self and others with decency, and justice understood broadly, might seem to exhaust the moral sphere."

Insert Table 1 about here

Like everything else about nexus-of-contracts organizations, their goodness is fragile. These organizations are built on the associative principle of accommodation (Pettit, 1993: 
299), which states that organizational participants do not join the organization because they perceive any inherent attraction in cooperating, but merely because their association offers them the best possible deal given the circumstances (see Table 1). It is not that nexus-ofcontracts organizations may not harbor appealing constellations of virtue, but the problem from an organizational morality perspective is that these constellations are not durably institutionalized. When more attractive outside options present themselves to some participants, the sum of corporate goodness will change as a result of turnover. Moreover, if the organization is subjected to crowding processes (Frey, 1998), whereby morally developed agents leave the organization first, the sum of moral qualities of the organization diminishes.

\section{The Utilitarian Organization}

The second organizational type we distinguish here is referred to by Etzioni as the utilitarian organization. Social units captured by this term are "organizations in which remuneration is the major means of control over lower participants and calculative involvement (i.e., mild alienation to mild commitment) characterizes the orientation of the large majority of lower participants" (Etzioni, 1975: 31). Although some degree of continuity exists between nexusof-contracts and utilitarian organizations, the differences between them are more substantial. Importantly, utilitarian organizations are founded on a different principle of association,

notably: the principle of compromise (Pettit, 1993: 299; see Table 1). Here the parties are induced to approve of certain moral or amoral principles of organization. These principles are not commonly recognized as inherently attractive, as each organizational member approves of them for varying sets of reasons, but at least the value of joint action and of the principles that ought to govern it are recognized by all. We illustrate below how this respect for joint purpose translates into a different conception of organizational goodness. 
Since the notion of virtue is contingent upon telos, we first describe how the organizational telos is uncovered in utilitarian organizations. The process of contracting into the utilitarian firm sets the conditions under which some form of corporate purpose or telos can emerge endogenously from the complex of strategic decisions made by the contractors (cf. Aoki, 2001). In each nascent organization there are typically a number of different cooperative solutions, which are all more or less acceptable to all parties involved (Sugden, 1989). Contractors therefore face a so-called coordination game (cf. Lewis, 1969), which centers on selecting a particular solution from this broader set. The standard apparatus of game theory teaches us that what is needed here is a "salient solution" or a "focal point" that helps contractors coordinate their efforts (Lewis, 1969). This solution, which Aoki (2001) calls a "shared-beliefs cum summary-equilibrium," emerges during the process of contracting into the utilitarian firm, because rational contractors will not just consider what is in it for them individually but also reflect on what ends are achievable collectively. Coordination problems are thus resolved when decision makers rationally adjust their behavior to the choices other decision makers have made in the past or are likely to make in the future. This process is wholly endogenous, in that it does not rely on extra-organizational information cues or enforcing mechanisms to come about (Aoki, 2001). Corporate purpose in utilitarian organizations is therefore best conceived as an emergent collective property of the practice of contracting into the firm, given the restrictions imposed on this process by the reasons other contracting parties have for joining the cooperation (Heugens et al., 2006).

Which conception of corporate goodness fits the utilitarian organization best? As utilitarian organizations are oriented towards a collective goal, the traditional self/other distinction that features so prominently in conceptions of person-oriented ethics no longer holds (see Table 1). In addition to caring about self and others, members of a "good" utilitarian organization must also appreciate the fact that they act and decide together. This 
calls for so-called virtues of common pursuit. In the words of one contributor: "Apart from the particular activities and products that may define a species of community, we value doing things with others (...) A willingness to compromise, to seek consensus, to be trustworthy and fair, all go with valuing collective endeavor. Similarly, loyalty to worthwhile, collective goals can be morally virtuous" (Sherman, 1993: 278).

This distinction between self- and other-directed virtues on the one hand, and the virtues of common pursuit on the other, dates back to Aristotle. From the NE, most will remember the list of self- and other-directed virtues: courage, temperance, liberality, magnificence, magnanimity, etc. But two of the ten books of the NE deal with the virtues of affiliation (philia; Books VIII and IX). In these books, one of the most famous Aristotelian dictums ("Humans are by nature social, for even when they have no need of assistance from one another, they still desire to live together" Politics 1278b) is put to work. It is demonstrated that the achievement of greater happiness for all requires all collaborants to recognize the value of their joint pursuit, and muster their individual excellences towards a collective goal. As voiced in IX.8: "If all were to strive (hamillōmenōn) towards what is fine and strain every nerve to do the finest deeds, everything would be as it should be for the common weal" (NE 1169a). In sum, to realize a collective telos, a utilitarian organization should harbor sufficient virtues of collective pursuit to induce all individual participants to gather their individual excellences behind its collective ambitions.

Yet, even though the virtues of collective pursuit are geared towards collective purposes, they are still nested in the individual organizational participants. Granted, the virtues are partially institutionalized in that they are shared amongst participants through joint action and communication, which makes the utilitarian organization somewhat more resilient than the nexus-of-contracts organization. But institutionalization of the virtues is only partial precisely because they are only shared amongst the present participants. They are not 
enduringly engraved in some extra-personal organizational system like a virtuous climate or culture. This makes utilitarian organizations vulnerable to turnover. Individual members may not leave the organization immediately in case a marginally better outside option comes along because of their endorsement of the collective purpose, but when turnover does occur, part of the organization's stock of virtues literally walks out the door. Unless the departed members can rapidly be replaced with other participants willing to endorse the collective telos, the organization will see its sum of moral qualities diminish.

\section{The Moral Community}

A third organizational type is the moral community. We treat moral communities as collective actors, in that they are higher-order agents, who can be the bearer of properties that cannot be reduced to the properties of lower-order participants (Etzioni, 1968; Laumann and Marsden, 1979). Some debate exists as to whether collective actors can be moral actors in their own right. Velasquez (2003), for example, rejects the notion of collective moral agency: "The fact that a collection of entities has properties that cannot be attributed to any of its members, does not show that the collection is a distinct real individual identity" (p. 541). But Velasquez rejects the possibility of collective moral agency on the wrong grounds. The question is not whether organizations must or must not be seen as entities with independent ontological status, as this is not a necessary condition for moral agency. The question is simply whether organizations can collectively possess the type of properties that are necessary and sufficient conditions for collective moral agency - irrespective of their ontological status. ${ }^{3}$

In general, three properties must be present in organizations before we can speak of them as moral communities (Heugens et al., 2006; van Oosterhout et al., 2006). It is best to see these properties as boundary conditions to collective moral agency; if any of them is transgressed, the moral community regresses towards a utilitarian organization. The first 
boundary condition is that organizations must collectively be autonomous to bind themselves to a set of self-imposed moral constraints (Rawls, 1971). Autonomy is relevant because it allows organizations to make promises that fully reflect their telos. According to Rawls (1971), autonomy guarantees that parties "are acting from principles that they would acknowledge under conditions that best express their nature as free and equal beings" ( $\mathrm{p}$. 515). Autonomy is thus a necessary precondition for collective moral agency.

Second, to realize a collective telos, the interests of organizational constituents must to a certain extent be morally and materially alignable. Collective moral actors must find a way to withstand the centrifugal force of self-motivated behavior, which allows private morals to prevail over collective morals. This primacy of private morals can easily erode a collective moral actor's ability to work towards collective goals. To overcome this predicament, moral communities need more than an endogenously discovered common focal point. On top of this common goal, they must have an incentive structure or administrative system in place that is robust against at least minor defections (Sugden, 1989). In moral communities, the sharedbeliefs cum summary-equilibrium is thus stiffened by structures and systems that make the attainment of individual goals dependent on the attainment of collective goals.

Third, organizations must have the ability to abide by the promises they make. Due to the telos-dependent nature of organizational virtues, it is impossible to substantively denote what the virtues of organizations in general ought to be (Heugens et al., 2006). As autonomous creatures, moral communities have the structural capacity to commit themselves to virtually anything. This does not make their relevant set of virtues empty or indeterminate, however. To be capable of collective moral agency, organizations must possess that precise set of skills that allows them to realize their self-selected telos (MacIntyre, 1985). Without these, organizations would repeatedly be forced to go against their own principles or break their promises, thus proving themselves incapable of collective moral agency. Although it is 
impossible to denote a generic set of substantive virtues that all organizations must possess, it is therefore at least theoretically possible to identify a set of specific virtues for each individual organization, provided that we know its telos.

If these boundary conditions are met, organizations can in principle evolve into moral communities. Whether this will happen is contingent upon a set of organizational and managerial factors, which we discuss in a following section. What binds such communities together is that they act according to the associative principle of shared reasons (Pettit, 1993: 299). At their heart lies a set of "rules for the general regulation of behavior which no one could reasonably reject as a basis for informed, unforced general agreement" (Scanlon, 1982: 110). These rules are endorsed by all participants in the community, on the basis that they have certain universal and intrinsic attractions. This contrasts with the operating logic of the utilitarian organization, wherein all participants abide by organizational principles for private and extrinsic reasons. It contrasts even sharper with the associative principle of the nexus-ofcontracts organization, in which no constitutive principles are shared at all. When a given community possesses intrinsically valuable principles, it has become "infused with value beyond the technical requirements of the task at hand" (Selznick, 1957: 17). Its telos no longer hinges on the realization of extrinsic benefits, but has become endogenized. It may even consist of the thriving and prolongation of the moral community itself (see Table 1).

What makes moral communities resilient is that they are fully institutionalized collective actors. They are unique in that they meet a number of boundary conditions to collective moral agency that are not met by the other organizational types. Qualities like autonomy, alignability, and ability have a high degree of social facticity to them. Such emergent properties materialize as rules, traditions, or conventions out of the repeated social interactions in a group of social actors (Weick, 1979). These focal points are resilient precisely because they are detached from the individual community members that once 
created them through their dealings with others, making them robust against turnover. In fact, the most likely cause of failure in moral communities is a slow decay of the social fabric that binds them together through the deinstitutionalization of these shared virtues (Oliver, 1992).

\section{Normatively “Good” Organizations}

So when is an organization morally good? It is tempting to proclaim the moral community a "better" organizational type than the utilitarian organization or the nexus-of-contracts, but this conclusion seems philosophically unwarranted. What matters in virtue ethics is the degree of congruence between the telos a given organization pursues and the set of virtues it harbors. All three organizational types can be congruent or incongruent in this sense. Hence, the nexus of contracts organization, which strives towards individual utility maximization, is morally good to the extent that all its members possess adequate self- and other-regarding virtues (see Table 1), but is morally underdeveloped in case its members lack these virtues. Similarly, the utilitarian organization, which strives towards collective utility maximization, is morally good to the extent that all its members possess the skills to recognize and realize the value of common pursuit (see Table 1), but lacks in moral development in case a fraction of its membership is exclusively concerned with their private interests. Finally, the moral community, which strives towards self-selected collective goals, is morally good when it meets the boundary criteria for collective moral agency (see Table 1), but is lacking in moral development in case it fails to meet them. Two conclusions about this typology seem warranted. First, it does not imply a rank-ordering in terms of moral goodness amongst the three organizational types. All three can be equally good, provided that their virtues match their telos. Second, not all real life organizations are morally good, in that many experience purpose-virtue incongruency. The thesis we develop below is that such organizations are not only prone to moral defects, but also to illegitimacy and organizational failure. 


\section{A PROCESSUAL MODEL OF ORGANIZATIONAL ‘GOODNESS’}

Whereas organizational goodness can manifest itself in all organizational types, it is relatively robust in the moral community, more fragile in utilitarian organizations, and frighteningly frail in the nexus of contracts. Our goal is to explain in a positive sense why the resilience of goodness varies across organizational types. To that effect we introduce a processual model, showing how the three organizational types are connected and how social collectives can develop from one type into another. At the core of our model lies the assumption that there is nothing inevitable about this developmental process, and that each transition phase is contingent upon managerial agency. Managers are not automatons, and they have to decide for themselves in each individual case whether they are willing to put their weight behind an organizational transition. The dynamism in our model thus primarily derives from managers' motivations, and only to a lesser extent from exogenous forces. Even though our graphical display seems to resemble a self-propelling process, we explicitly wish to avoid any reference to an inevitable evolutionary process (see Figure 1).

Insert Figure 1 about here

The contributions of this model are threefold. First, it offers a positive theory of organizational goodness in that it introduces a developmental perspective on organizational virtue, tracing goodness to its empirical antecedents and consequences. Few virtue ethicists attempt to connect virtue theory with positive theorizing, and to the best of our knowledge, no processual model of the development of organizational virtue is available to date. A second contribution of is that the model is grounded in the literature on management and organization, which establishes a new level of connectivity between virtue ethics on the one 
hand and established organizational theories on the other. The model is in its entirety related to organizational institutionalization theories (the "old" institutionalism; cf. DiMaggio and Powell, 1991: 11-15). Elements of the model are nested in other perspectives on management and organization, such as imprinting theory (Stinchcombe, 1965) and organizational legitimacy theory (the "new" institutionalism; cf. DiMaggio and Powell, 1991: 11-27), as well as the upper echelon perspective (Hambrick and Mason, 1984) and the strategic middle management perspective (Floyd and Lane, 2000; Floyd and Wooldridge, 1992). A third contribution is that the model unifies several connotations of organizational goodness. Precisely, the model explicates the conditions under which "moral goodness" will lead to “practical excellence.” As such, the model offers a fresh perspective on our research question.

\section{The Dawn of Virtue: From Nexus-of-Contracts to Utilitarian Organization}

Nexus-of-contracts organizations emerge when two or more contractors jointly decide that it is in their best interest to structure their future transactions via a formal organization rather than through the market. Many different reasons can lead them to this conclusion. One of these is that integration might end socially destructive haggling over "appropriable quasirents" (Klein et al., 1978) which stem from asset-specific investments. As Williamson puts it: "fiat is frequently a more efficient way to settle minor conflicts (...) than is haggling" (1971: 114-115). For as long as their investments in dedicated assets remain a potential source of private pecuniary gain to their counterparts, contractors will be better off when they pool these assets in a joint organization, coordinated by a "boss" who is authorized to "cut the Gordian knots" of decision-making (Perrow, 1986: 25). Another reason favoring integration is that adaptation to unforeseen circumstances is difficult in markets where uncertainty abounds (Simon, 1951). The contractors must choose between (a) negotiating a market exchange contract before the uncertainty about the future situation is resolved or (b) allocating authority 
to a "boss," who can then make an adaptive decision after the uncertainty has cleared up. The more the value of a given transaction is contingent upon post-hoc adaptation, the more attractive the internalization option becomes (Klein, 2000). These observations point out that the most central agent in any nascent firm's virtue institutionalization process is likely to be its first top manager or the founding top management team. See Proposition 1:

Proposition 1: Nexus-of-contracts organizations emerge when two or more prospective contractors appoint an ultimate authority to protect their dedicated investments or avoid the problem of adaptation.

In economic theories of the firm, all parties in the nexus-of-contracts are drones in that they are purportedly guided by a general model of self-interested action that makes them both (a) completely predictable and (b) perfectly interchangeable (Bowles and Gintis, 1993). We have advocated a more socialized version of the nexus-of-contracts, by allowing its constituent contractors to be the carrier of self- and other-regarding virtues (see Table 1). We now further socialize the nexus-of-contracts organization by allowing its ultimate authority a distinctive identity. Prior studies have shown that the identity of the founder/top manager is likely to spill over to the identity of the organization through imprinting, "a process in which events occurring at certain key developmental stages have persisting — perhaps lifelongconsequences" (Hannan, 1998: 132) for the organization. Imprinting is contingent upon the identity of the founder/top manager, as founders build organizations that not only fit historically specific environments, but also cohere with their personal ambitions and life philosophies (Stinchcombe, 1965). Top managers thus play a leading role in the development of a firm from a nexus-of-contracts to a utilitarian organization. If they envisage a collective purpose for the organization, it is usually within their power to impose this vision on the core 
group of founding contractors (Schein, 2004). Similarly, leaders can over time instill the virtues of common pursuit in their organizations through socialization and selective recruitment and dismissal (Schein, 2004). See Proposition 2:

Proposition 2: Nexus-of-contracts organizations develop into utilitarian organizations when top managers succeed at infusing the organization with a sense of collective purpose and its members with the virtues of common pursuit.

Not all top managers make it a priority to spur the development of the nexus-ofcontracts organization into a utilitarian organization. Some may see their organizations primarily as vehicles for furthering their private interests - a view that certainly underlies most of the present-day literature on corporate governance (Shleifer and Vishny, 1997). Selfinterested managerial behavior fundamentally affects the organizational climate, even when no malevolence is involved. Such behaviors have a tendency of crowding out what Frey (1997) calls "civic virtues" and what we have called the "virtues of common pursuit." The hidden cost of running an organization for personal gain is that it can alter the intrinsic motivation of other participants. Specifically, participants' interests in furthering a collective purpose will diminish when top managers refrain from stressing its importance. This effect increases when the interaction between leader and participant is greater, as the template of egoism then gains greater influence on the latter (Frey, 1997, 1998). This crowding effect coalesces with the fact that nexus-of-contracts organizations are 'hardwired' for straightforward dissolution. The nexus' temporary equilibrium will persist only for as long as all members see it as their first-best chance of realizing their private interests. If members find that they are better off joining another nexus, they will simply leave. See Proposition 3: 
Proposition 3: If top managers persistently crowd out any emerging sense of collective purpose or the virtues of common pursuit, nexus-of-contracts organizations will be dismantled as soon as the value of an outside option exceeds that of prolonged membership for nontrivial contractors.

\section{Passing the Baton: From Utilitarian Organization to Moral Community}

If top managers want to see their organizations develop from utilitarian organizations to moral communities, they have to rethink their internal structures and control systems. In utilitarian organizations, the role of middle managers is traditionally modeled after the "command and control" perspective, in which their primary responsibilities are implementing leaders' visions and supplying them with information synthesized from lower organizational levels (Floyd and Lane, 2000; Floyd and Wooldridge, 1992). Since decision-making powers are concentrated at the top, there is little room in such organizations for what Westley (1990) calls "strategic conversations" - communications between senior and middle-level management that precede, accompany, and follow actual strategy decisions. Such narrow conceptions of the role of middle managers fail to stimulate the development of a moral community for two reasons. First, the importance of substantive organizational virtues - like carefulness or audacity, temperance or aggression - differs across business contexts. Different virtue constellations may durably co-exist in a single organization, which makes it undesirable to have them centrally ordained from a strategic apex. Second, developing the type of collective telosspecific virtues that characterize the moral community requires substantive interaction between top and middle managers about strategic issues. The effect of virtuous behavior by top leaders is likely to be annulled when local leaders are excluded from the strategic conversations in which organizational goals are set and individual standards of behavior are expressed. To stimulate the development of moral communities, top managers must involve 
middle managers in the conversations that give organizations strategic direction. This requires investments in systems allowing middle managers to converse cross-functionally around strategic issues (Westley, 1990: 349). See Proposition 4:

Proposition 4: The development of utilitarian organizations into moral communities requires that top managers share the responsibility for the development of a collective telos and collective virtues with middle managers.

Middle managers play an important role as agents of change in the development from utilitarian organization to moral community. They decide whether organizations meet the boundary conditions for collective moral agency. In terms of autonomy, the crucial matter is whether middle managers capitalize on the delegation of responsibility for the development of a collective telos and collective virtues by top managers (cf. Proposition 4). If they embrace their new responsibilities, they can make the organization capable of committing collectively to a self-selected telos. With respect to alignability, middle managers play an equally important role. The problem of organizational governance is often simplistically portrayed as the problem of keeping top managers in check on behalf of shareholders (cf. Shleifer and Vishny, 1997). But agency problems exist at all levels of the organization. If middle managers are willing to put their weight behind organizational systems that address noncompliance, these lower-level agency problems can fruitfully be addressed. Finally, in terms of ability, organizational virtues are best conceptualized as a set of organizational skills. It is therefore not surprising that middle managers, who play a crucial role in the development of a firm's competitive potential through the definition, deployment, and modification of its competitive capabilities (Floyd and Lane, 2000), also play a central role in the development of its moral virtues. See Proposition 5: 
Proposition 5: Utilitarian organizations develop into moral communities when middle managers successfully help the organization meet the boundary conditions for collective moral agency.

Middle managers often do not succeed at infusing the organization with collective virtues, however, for which there are two main causes. First, top managers may bar them from participating in strategic conversations (Westley, 1990; cf. Proposition 4). Floyd and Wooldridge $(1992,1994)$ report that many top managers perceive it as their role to make strategic decisions, which leads them to exclude middle managers from all discussions apart from those on operational matters. Middle management's attempts at furthering new initiatives, including the development of new virtues, often fall on deaf ears with top management. When middle managers lack the power to set norms, discuss them with subordinates, and sanction the latter according to their performance, moral development is bound to stagnate. A second cause for moral stagnation manifests itself when middle managers experience role conflict (Floyd and Lane, 2000) in their efforts to enhance the collective "goodness" of their organization (cf. Proposition 5). The middle-managerial responsibilities associated with the day-to-day operations of a business firm require a focus on the short to intermediate term, an emphasis on cost reduction, and the development of operational goals that are closely aligned with the deliberate strategy of the firm. In contrast, the development of collective virtues dictates a focus on the longer term, demands substantial investments, and calls for visionary goals that diverge from corporate orthodoxy. If middle management is not equipped to balance these competing responsibilities, the moral development of the organization will stagnate. As they remain in their utilitarian state, organizations will fail when the collective telos loses its appeal to some or all of their members (cf. Table 1). See Proposition 6. 
Proposition 6: If middle managers are unable to promote the moral development of utilitarian organizations, these organizations will be dismantled as soon as their collective teloi lose their attractiveness in the eyes of their members.

\section{Goodness’ Payoff: The Consequences of Moral Community Status}

The link between corporate social performance (CSP) and corporate financial performance (CFP) is a popular topic for empirical research in business ethics (Husted and De Jesus Salazar, 2006; McWilliams et al., 2006). Yet the empirical support for this link is mixed, as positive effects alternate with neutral and negative effects. Our model offers a new specification of the CSP-CFP association, suggesting that it is moderated by organizational type. We propose a contingency thesis which takes into account the so-called 'double-edged sword' mechanism (Ashforth and Gibbs, 1990). A core observation is that any decision by an external actor to contribute substantively to the increased effectiveness of an organization, either by endorsing its purpose or by making necessary resources available to it, is preceded by a social judgment (cf. Pfeffer and Salancik, 1978). Through it, the actor determines whether an organization is worthy of support. But organizations who deliberately pursue activities to influence the decision-making processes of the actors upon whom they depend are at risk of being perceived as instrumental and manipulative (Ashforth \& Gibbs, 1990). Nexus-of-contracts and utilitarian organizations are especially vulnerable in this respect, because they will by design only pursue activities that can be reconciled with their members' goal of utility maximization. For these organizations, additional investments in CSP are likely to reduce the support they receive from their external constituents, leading to lesser performance. In contrast, we expect to see a positive CSP-CFP link for moral communities, since outsiders are more likely to perceive of these organizations' CSP activities as part of their identity. Moral communities can thus count on an 'authenticity bonus,' which helps them 
avoid the 'double-edged sword' mechanism. As this 'bonus' is unlikely to accrue to nexus-ofcontracts and utilitarian organizations, the latter are likely to be outperformed in substantive terms by moral communities. See Proposition $7 .^{4}$

Proposition 7: Investments in CSP are more likely to furnish additional outside support for moral communities than for nexus-of-contracts or utilitarian organizations, as the latter parties' efforts are more likely to be perceived as instrumental or insincere.

The correlates of effectiveness - quality, efficiency, reliability - help organizations cope with technical environmental pressures (Meyer and Rowan, 1977). But technical excellence does not guarantee success, as organizations must also cope with institutional pressures, although the strength of these varies across environments (Meyer and Scott, 1983). Institutional pressures manifest themselves as rule-like prescriptions concerning organizations' structure and behavior, which emanate from regulative bodies, exemplary organizations, or the professions (DiMaggio and Powell, 1983). When organizations publicly demonstrate their conformity to these rules, they are enacting their own legitimacy, defined by Suchman as a "generalized perception or assumption that the actions of an entity are desirable, proper, or appropriate within some socially constructed system of norms, values, beliefs, and definitions" (1995: 574). Most studies to date focus on the cognitive legitimacy of organizations (Mizruchi and Fein, 2000). This involves a sort of taken-for-grantedness, acquired as the organization mimics the structures or behaviors of highly visible or topperforming organizations in its field, such that it "fades into the background" and escapes further scrutiny (Jepperson, 1991). A relatively underexplored - but potentially no less important - type is moral legitimacy, which rests on a positive normative evaluation of the 
organization and its behaviors (Parsons, 1960). Moral legitimacy is attributed to an organization when outsiders, rather than judging the organization in terms of the contributions it makes to their narrow self-interests, assess it against a pro-social logic in which the good of the evaluator fuses with the good of society as a whole (Suchman, 1995). Arguably, seen through radically libertarian eyes, nexus-of-contracts firms and utilitarian organizations can be seen as morally legitimate creatures as long as they contribute to the advancement of the interests of the individuals partaking in them, irrespective of the consequences for social justice (cf. Nozick, 1979). As a matter of fact, however, the libertarian point of view has never gained a strong foothold in most liberal democracies. In most contemporary societies, it is common to hold firms accountable - albeit to varying degrees - for their performance on broader, more inclusive social criteria. Since the moral community is the only organizational type that functions according to this broader moral logic by design, it is more likely to furnish moral legitimacy than the other types. See Proposition 8.

Proposition 8: Moral communities are more likely to be perceived as morally legitimate than nexus-of-contracts or utilitarian organizations.

Collective moral agency is a self-sustaining quality in that it allows organizations to increase their effectiveness by avoiding the "double-edged sword" mechanism that might otherwise decrease the support of their outside audiences (cf. Proposition 7). It also allows them to evoke moral legitimacy, if they find a way to let their moral qualities carry over to outside audiences guided by a pro-social frame of mind (cf. Proposition 8). Moral communities are therefore able to fend off technical and institutional pressures, due to their control over the moral aspects of their behavior. But this does not make them immune to failure. Their Achilles' heel is that their resilience depends on the sustained institutionalization of collective 
virtues, which calls both for steady allocations of financial, human, and social capital towards their maintenance and for their constant reenactment in concrete organizational behaviors. Researchers of deinstitutionalization have argued that especially technical pressures can cause organizations to abandon such broadly endorsed practices (Oliver, 1992). When stagnant economic performance or lowered innovativeness forces organizations to rethink their current business practices, priorities can shift from the sustenance of collective virtues towards the adoption of new managerial fads that harbor the promise of greater productivity (Zuckerman, 2000). Other researchers have found that technical pressures do not stand alone as antecedents of deinstitutionalization. Institutional pressures simultaneously shape the pace and process of deinstitutionalization (Ahmadjian and Robinson, 2001). When evaluators switch from a prosocial evaluation logic to a more narrowly self-centered one, for example, the institutional rationale behind maintaining collective virtues withers. See Proposition 9.

Proposition 9: If moral community members are unable to fend off technical and institutional pressures urging the deinstitutionalization of collective virtues, their organization will lose its moral community status.

\section{DISCUSSION AND CONCLUSION}

A single research question has guided our efforts in this paper: What does it take to be a good company? In this concluding section we condense the arguments presented here into both a normative and a positive answer to this question. Furthermore, we discuss the implications of our analyses for practitioners, and reflect on how our efforts might impact the academic field of business ethics. 


\section{A Normative Take on Organizational Goodness}

Normatively, corporate goodness equals "moral goodness," which is typically conceptualized in virtue ethics as the exercise of one's virtues in accord with one's purpose or telos. In a person-centered version of virtue ethics, such as Aristotle's, this conception is unproblematic as all individuals are expected to pursue a single end, namely eudaimonia or "happiness.", For Aristotle, all other ends are pursued because they are instrumental in obtaining others, but happiness is something "we always choose (...) for itself, and never for any other reason" (NE 1097b). Thus, eudaimonia alone is the only end we can "call final without any qualification" (NE 1097a).

Unfortunately, this singular conception of telos does not apply to the corporate world, as organizations are highly pliable instruments that can cater to practically any need. This renders it impossible to speak in general terms about organizational goodness. But we need not throw the baby out with the bathwater and commit ourselves to moral relativism. We object to a view of organizational goodness as something unique or idiosyncratic. To substantiate this point, we suggested a Mertonian theory of the middle-range which groups organizations in three classes according to their telos. Some organizations advance the private good of all parties partaking in them, and these nexus-of-contracts organizations are morally good as long as their members possess adequate self- and other regarding virtues. Other organizations advance some collective good for their members, and these utilitarian organizations are congruent to the extent that their members hold virtues of common pursuit. A final class of organizations is capable of pursuing intrinsically attractive collective goals, and such moral communities are morally good as long as they meet the boundary criteria for collective moral agency. Thus, the normative take on corporate goodness suggests that organizations are morally good as long as they possess virtues that are appropriate for the class of organizations to which they belong. 


\section{A Positive Take on Organizational Goodness}

When incorporated in positive theories of organizations, "goodness" is usually operationalized in terms of "practical excellence." This second connotation raises the challenge of connecting notions of organizational virtue to practical outcomes like legitimacy and efficiency. We introduced a processual model of organizational development, which specifically draws attention to the differential roles played by top and middle managers in periods of organizational transition. Top managers are instrumental in developing nexus-ofcontracts organizations into utilitarian organizations. In the early stages of organizational development, they are the ones who must initially take the lead at infusing the organization as a whole with a sense of collective purpose, and its constitutive members with the virtues of common pursuit. If they succeed, their organizations will become morally more resilient, and more likely to survive periods in which organizational cohesion is threatened by increasingly attractive outside options for critical organizational participants.

But at some point in organizational history, top managers must begin to involve middle managers in their strategic conversations. Once middle managers themselves transform from lethargic paladins to true "change masters" (Kanter, 1983), the organization becomes ready to develop from a utilitarian organization into a moral community. The success of this transformation is crucially dependent on middle managers' efforts to help their organizations meet the boundary criteria for collective moral agency. Only middle managers can establish the necessary conditions of autonomy, alignability, and ability by encouraging lower-level organizational participants to commit collectively to a self-selected telos, by contributing to the resolution of organizational governance problems, and by developing the virtues necessary to realize the aforementioned telos. If successful, they can make the moral community resilient against moral failure, and lead it to unprecedented efficiency and legitimacy. 


\section{Implications for Managers, Consultants, and Policy Makers}

We see the practical value of our work primarily in the area of ethical diagnostics. Our model offers managers, consultants, and policy makers a new framework for analyzing corporate moral failure. In business ethics, explanations for ethical failure are usually of the so-called “bad apples/bad barrels" kind (Treviño, 1986; Treviño and Youngblood, 1990), implying that the cause of ethical problems is commonly traced either to unethical individuals (the "bad apples") affecting the morals and motivations of those around them, or to ineffective organizational bureaucracies (the "bad barrels") which corrupt even well-intending individuals by exposing them to dysfunctional informational cues and reward systems. Whereas these explanations are intuitively appealing, they are too simplistic to shed much light on complex cases of moral failure like the ENRON or WorldCom affairs. Our model offers a different take on the issue by stipulating two complementary paths leading to organizational moral demise. We label these paths moral stagnation and moral drift.

Moral stagnation. All three organizational types harbor the promise of moral goodness, in the sense of them being capable of experiencing virtue-telos congruence. But whereas this type of congruence is relatively robust in moral communities, it is considerably frailer in utilitarian organizations and nexus-of-contracts organizations. Our argument is not that all organizations should strive to become moral communities, but if their goal is to become more robust against moral predicaments and to maximize their legitimacy and efficiency, this is still their best option. If top and middle managers refuse to direct their efforts towards this more institutionalized state of affairs, moral stagnation - a tendency towards inertia in an organizational form incapable of collective moral agency - is likely to set in. As a result, the morally stagnant organization will become more prone towards moral failure than its morally more advanced counterparts. Provided that a transparent informational regime is in place, moral stagnation should lead to a higher cost of external capital for 
organizations, and to less willingness on behalf of outside constituents to contribute to longrun organizational flourishing.

Moral drift. Any temporary alignment between an organization's telos and its pool of virtues, alas, offers no guarantees for future congruence. Without sufficient "maintenance work" by top and middle managers, all organizations are at risk of losing their state of virtuousness to moral drift - a dysfunctional developmental process resulting in a state of incongruence between an organization's telos and its corresponding set of virtues. In the nexus-of-contracts organization, which' virtues are fully reducible to those of its individual constituents, moral drift often takes the form of a crowding process. When members with a stock of self- and other regarding virtues that is sufficiently developed to allow them to stand their moral ground in the process of commerce are replaced by individuals with less selfimposed restraint, nexus-of-contract organizations are bound for moral failure. In utilitarian organizations, moral drift occurs when the virtues of common pursuit are hollowed out from within - when top and middle managers do too little to maintain them, or from the outside when the alternate options available to critical organizational constituents become too attractive to turn down. In the moral community, finally, moral drift occurs when the virtues that are crucial to collective moral agency are deinstitutionalized due to technical and institutional pressures on the organization and its members.

\section{Implications for Business Ethics and Management Scholars}

Rather than finishing our paper with the usual obligatory recommendations for future research, in which we would express the literally vain hope that future generations of business ethics and management scholars will spend their time and energy on conceptual refinement and empirical testing of our work, we close with a more general yet double call to arms for the fields of business ethics and management studies. First, we call upon scholars of both 
denominations to return to the intellectual foundations of the ethics field by grounding their future work more firmly in the centuries-old traditions of ethical theory. In case any of our readers see any merit in either our typology or developmental model, much of the credit will have to go to prior contributors to virtue ethics, accompanied by the usual disclaimer. We not only find sufficient inspiration in classic works for contemporary contributions, but also that younger, domain-specific approaches like the stakeholder and corporate citizenship perspectives simply do not meet the standards of intellectual rigor set by centuries of scholarly debate. Second, we urge scholars to focus in particular on ethical theories that are most fully compatible with the domain of management studies. Other scholars may prove us wrong, but this congruence criterion seems to disqualify Kantian ethics and utilitarianism, respectively due to their overly forbidding stance towards many of the widely accepted means of goal-attainment in business and untenable assumption of agent-neutrality. Two ethical theories, however, are characterized by an exceptionally high degree of connectivity with the domain of management studies. One is contractualist business ethics, due to its base in the notion of content-independent commitment (cf. van Oosterhout et al., 2006); the other virtue ethics, due to its emphases on skills and excellence (cf. Heugens et al., 2006). If scholars are seriously willing to ground their work more strongly in either of these perspectives, we fully expect the fruits of their labor to reach higher standards of rigor and relevance. 


\section{REFERENCES}

Ahmadjian, C. L., \& Robinson, P. 2001. Safety in numbers: Downsizing and the deinstitutionalization of permanent employment in Japan. Administrative Science Quarterly, 46(4): 622-654.

Alchian, A. A., \& Demsetz, H. 1972. Production, information costs, and economic organization. American Economic Review, 62: 777-795.

Aoki, M. 2001. Toward a comparative institutional analysis. Cambridge, MA: MIT Press.

Aristotle. 1976. The Nicomachean ethics. London: Penguin.

Bekker, I. 1831. Aristotelis Opera. Berlin: Reimer.

Bloomfield, P. 2000. Virtue epistemology and the epistemology of virtue. Philosophy and Phenomenological Research, LX(1): 23-43.

Bowles, S., \& Gintis, H. 1993. The revenge of homo economicus: Contested exchange and the revival of political economy. Journal of Economic Perspectives, 7(1): 83-102.

DiMaggio, P. J., \& Powell, W. W. 1983. The iron cage revisited: Institutional isomorphism and collective rationality in organizational fields. American Sociological Review, 48: 147-160.

DiMaggio, P. J., \& Powell, W. W. 1991. Introduction. In W. W. Powell, \& P. J. DiMaggio (Eds.), The new institutionalism in organizational analysis: 1-38. Chicago: University of Chicago Press.

Dosi, G. 1997. Opportunities, incentives and the collective patterns of technological change. The Economic Journal, 107(September): 1530-1547.

Etzioni, A. 1968. Mobilization as a macrosociological conception. The British Journal of Sociology, 19(3): 243-253. 
Etzioni, A. 1975. A comparative analysis of complex organizations: On power, involvement, and their correlates (2nd ed.). New York: The Free Press.

Etzioni, A. 1996. A moderate communitarian proposal. Political Theory, 24(2): 155-171.

Floyd, S. W., \& Wooldridge, B. 1992. Middle management involvement in strategy and its association with strategic type: A research note. Strategic Management Journal, 13: $153-167$.

Floyd, S. W., \& Wooldridge, B. J. 1994. Dinosaurs or dynamos? Recognizing middle management's strategic role. Academy of Management Executive, 8(4): 47-58.

Floyd, S. W., \& Lane, P. J. 2000. Strategizing throughout the organization: Managing role conflict in strategic renewal. Academy of Management Review, 25(1): 154-177.

Frey, B. S. 1997. A constitution for knaves crowds out civic virtues. The Economic Journal, 107: 1043-1053.

Frey, B. S. 1998. Institutions and morale: The crowding-out effect. In A. Ben-Ner, \& L. Putterman (Eds.), Economics, Values, and Organization: 437-460. Cambridge: Cambridge University Press.

Hambrick, D. C., \& Mason, P. A. 1984. Upper echelons: The organization as a reflection of its top managers. Academy of Management Review, 9(2): 193-206.

Hannan, M. T. 1998. Rethinking age dependence in organizational mortality: Logical formulations. American Journal of Sociology, 104(1): 126-164.

Heugens, P. P. M. A. R., \& van Oosterhout, J. 2002. The confines of stakeholder management: Evidence from the Dutch manufacturing sector. Journal of Business Ethics, 40(4): 387-403.

Heugens, P. P. M. A. R. 2005. A neo-Weberian theory of the firm. Organization Studies, 26(4): 547-567. 
Heugens, P. P. M. A. R., Kaptein, S. P., \& van Oosterhout, J. 2006. The ethics of the node versus the ethics of the dyad? Reconciling virtue ethics and contractualism. Organization Studies, 27(3): 391-411.

Husted, B. W. \& De Jesus Salazar, J. 2006. Taking Friedman seriously: Maximizing profits and social responsibility. Journal of Management Studies, 43(1): 75-91.

Jensen, M. C., \& Meckling, W. H. 1976. The theory of the firm: Managerial behavior, agency costs and ownership structure. Journal of Financial Economics, 3: 305-360.

Jensen, M. C. 1983. Organization theory and methodology. The Accounting Review, LVIII(2): 319-339.

Jepperson, R. L. 1991. Institutions, institutional effects, and institutionalism. In W. W. Powell, \& P. J. DiMaggio (Eds.), The new institutionalism in organizational analysis: 143-163. Chicago: University of Chicago Press.

Kanter, R. M. 1982. The middle manager as innovator. Harvard Business Review, 60(4): 95105.

Kanter, R. M. 1983. The change masters. New York: Basic Books.

Klein, B., Crawford, R. A., \& Alchian, A. A. 1978. Vertical integration, appropriable rents, and the competitive contracting process. Journal of Law and Economics, 21: 297326.

Klein, B. 2000. Fisher-General Motors and the nature of the firm. Journal of Law and Economics, 43: 105-141.

Laumann, E. O., \& Marsden, P. V. 1979. The analysis of oppositional structures in political elites: Identifying collective actors. American Sociological Review, 44(5): 713-732.

Lewis, D. K. 1969. Convention. Cambridge, MA: Harvard University Press.

MacIntyre, A. C. 1985. After virtue (2nd ed.). Notre Dame, IN: University of Notre Dame Press. 
McWilliams, A., Siegel, D. S., \& Wright, P. M. 2006. Corporate social responsibility: strategic implications. Journal of Management Studies, 43(1): 1-18.

Merton, R. K. 1968. Social theory and social structure. New York: Free Press.

Meyer, J. W., \& Rowan, B. 1977. Institutionalized organizations: Formal structure as myth and ceremony. American Journal of Sociology, 83(2): 340-363.

Meyer, J. W., \& Scott, W. R. 1983. Organizational environments: Ritual and rationality. Beverly Hills, CA: Sage.

Mizruchi, M. S., \& Fein, L. C. 1999. The social construction of organizational knowledge: A study of the uses of coercive, mimetic, and normative isomorphism. Administrative Science Quarterly, 44: 653-683.

Moore, G. 2005. Corporate character: Modern virtue ethics and the virtuous corporation. Business Ethics Quarterly, 15(4): 659-685.

Moore, G. \& Beadle, R. 2006. In search of organizational virtue in business: Agents, goods, practices, institutions and environments. Organization Studies, 27(3): 369-389.

Oliver, C. 1992. The antecedents of deinstitutionalization. Organization Studies, 13(4): 563 588.

Pence, G. 1991. Virtue theory. In P. Singer (Ed.), A companion to ethics: 249-269. Oxford: Blackwell.

Perrow, C. 1986. Complex organizations: A critical essay (3rd ed.). New York: McGrawHill.

Pettit, P. 1993. The common mind: An essay on psychology, society, and politics. Oxford: Oxford University Press.

Pfeffer, J., \& Salancik, G. R. 1978. The external control of organizations. New York: Harper and Row. 
Scanlon, T. M. 1982. Contractualism and utilitarianism. In A. Sen, \& B. Williams (Eds.), Utilitarianism and Beyond: 103-128. Cambridge: Cambridge University Press.

Schein, E. H. 2004. Organizational culture and leadership. San Francisco, CA: JosseyBass.

Selznick, P. 1957. Leadership in administration: A sociological interpretation. New York: Harper and Row.

Sherman, N. 1993. The virtues of common pursuit. Philosophy and Phenomenological Research, LIII(2): 277-299.

Shleifer, A., \& Vishny, R. W. 1997. A survey of corporate governance. Journal of Finance, 52(2): 737-783.

Simon, H. A. 1951. A formal theory of the employment relationship. Econometrica, 19: 293305.

Solomon, R. C. 2003. A better way to think about business: How personal integrity leads to corporate success. New York: Oxford University Press.

Stinchcombe, A. L. 1965. Social structure and organizations. In J. G. March (Ed.), Handbook of organizations: 142-193. Chicago, IL: Rand-McNally.

Suchman, M. C. 1995. Managing legitimacy: Strategic and institutional approaches. Academy of Management Review, 20: 571-610.

Sugden, R. 1989. Spontaneous order. Journal of Economic Perspectives, 3: 85-97.

Tomasi, J. 101. Individual rights and community virtues. Ethics, 101(April): 521-536.

Treviño, L. K. 1986. Ethical decision making in organizations: A person-situation interactionist model. Academy of Management Review, 11(3): 601-617.

Treviño, L. K., \& Youngblood, S. A. 1990. Bad apples in bad barrels: A causal analysis of ethical decision-making behavior. Journal of Applied Psychology, 75(4): 378-385. 
van Oosterhout, J., Heugens, P. P. M. A. R., \& Kaptein, S. P. 2006. The internal morality of contracting: Advancing the contractualist endeavor in business ethics. Academy of Management Review, 31(3): 521-539.

Velasquez, M. G. 2003. Debunking corporate moral responsibility. Business Ethics Quarterly, 13(4): 531-562.

Weaver, G. R. 2006. Virtue in organizations: Moral identity as a foundation for moral agency. Organization Studies, 27(3): 341-368.

Weber, M. 1949. The methodology of the social sciences. New York: Free Press

Weick, K. E. 1979. The social psychology of organizing (2nd ed.). New York: McGrawHill.

Williamson, O. E. 1971. The vertical integration of production: Market failure considerations. American Economic Review, 61: 112-123.

Williamson, O. E. 1985. The economic institutions of capitalism. New York: Free Press.

Zingales, L. 2000. In search of new foundations. Journal of Finance, 55(4): 1623-1653.

Zuckerman, E. W. 2000. Focusing the corporate product: Securities analysts and dediversification. Administrative Science Quarterly, 45(3): 591-619. 
TABLE 1

Three Types of Normatively Good Organizations

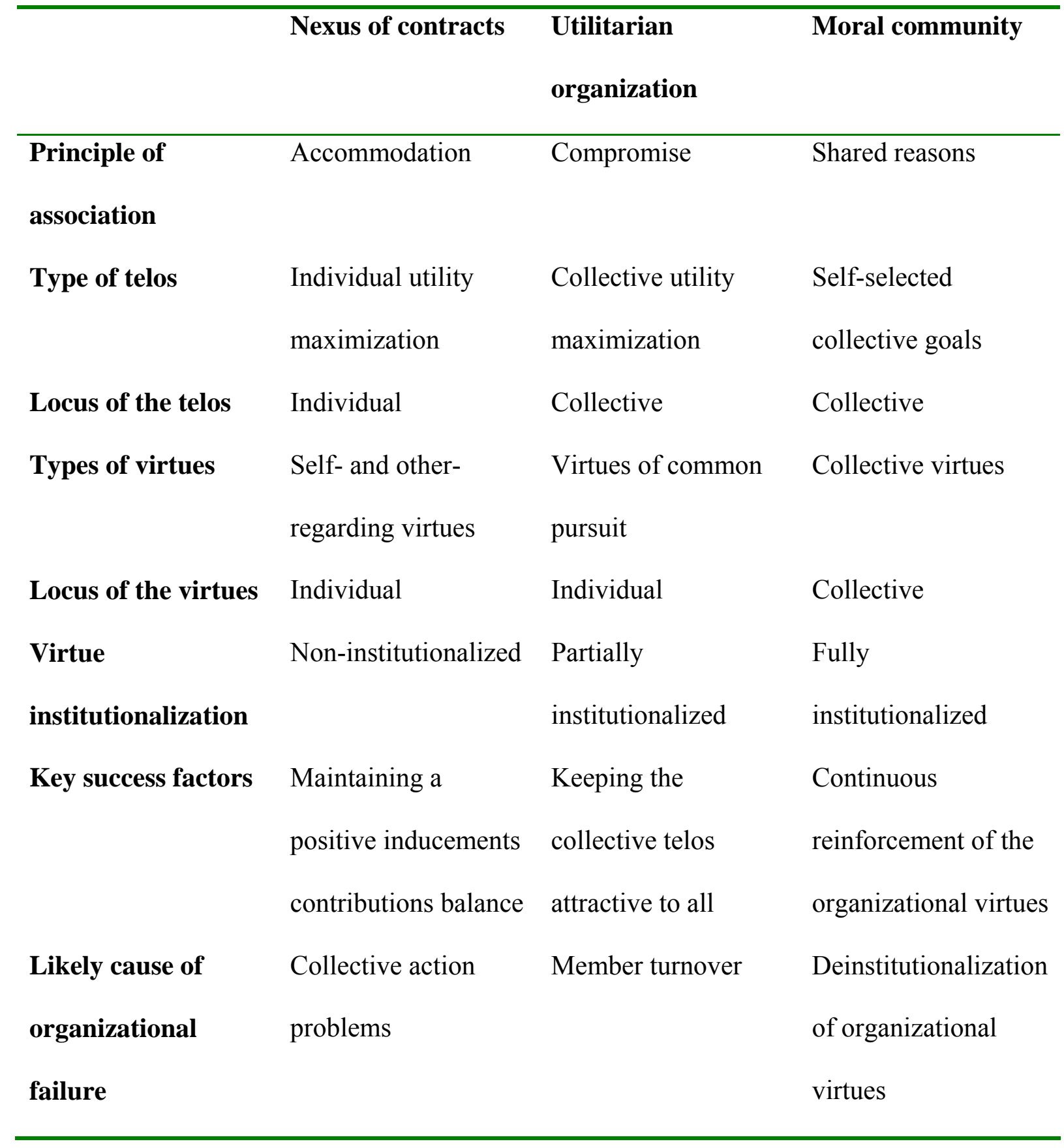


FIGURE 1

A Processual Model of Organizational Goodness

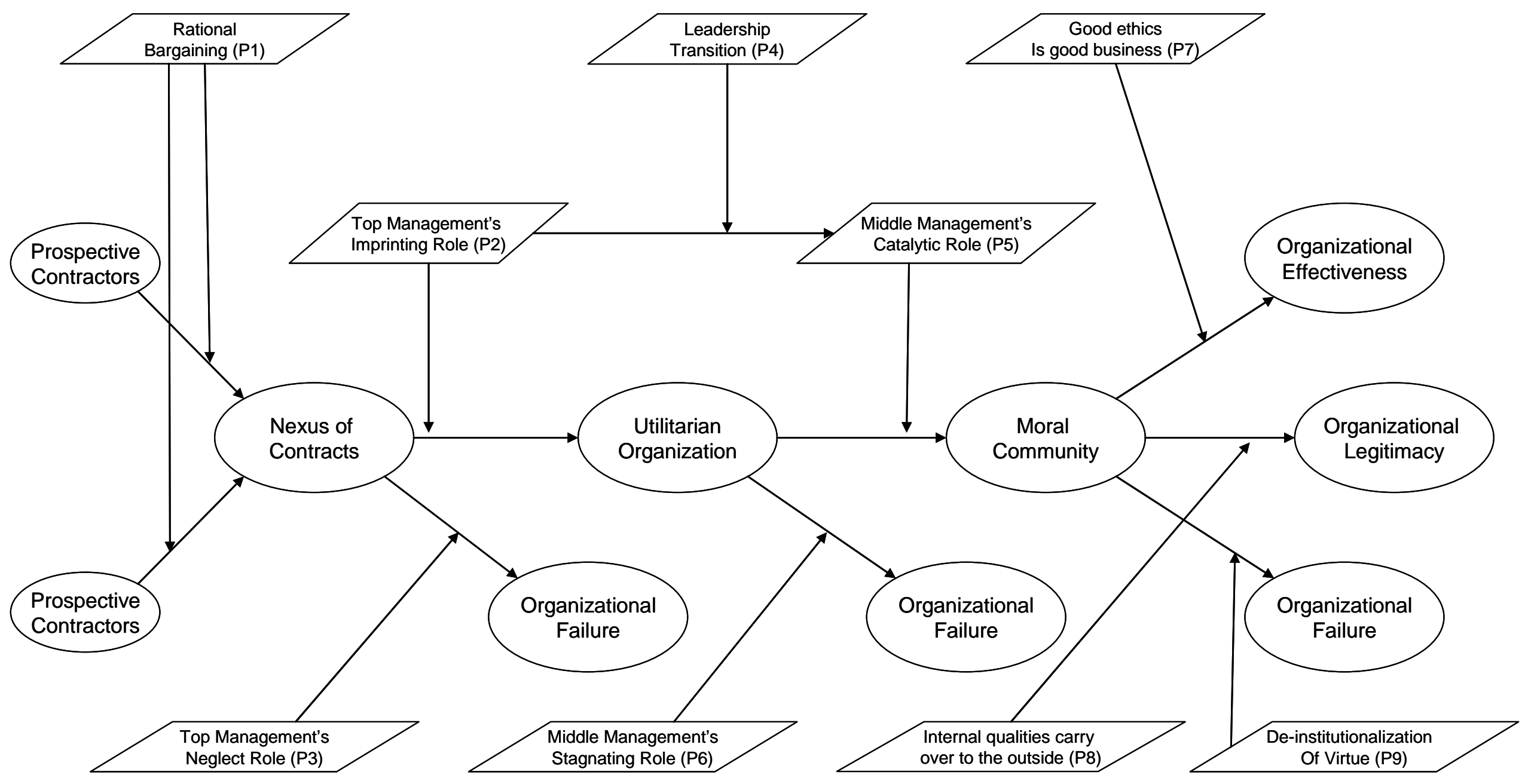




\section{ENDNOTES}

${ }^{1}$ The figures and letters refer to the corresponding pages and columns ("a" is left, "b" is right) of Bekker's (1831) Greek text of Aristotle's combined works, which are regularly used for giving exact references to his writings. English translations are taken from the 1976 Penguin edition of the Nicomachean Ethics.

${ }^{2}$ We stress that we do not seek to develop a taxonomy (a classification of extant organizations) but a typology (a conceptual sensegiving device which highlights certain elements common to most cases of the typified phenomena). The three organizational types we sketch are ideal types (Weber, 1949) in that they portray congruence between their purpose and virtues. Yet, many real life organizations do not experience such congruence, and are therefore prone to moral defects. Thus, we neither imply that all organizations are morally good, nor that our typology encompasses an exhaustive set covering all extant organizations and organizational types.

${ }^{3}$ Velasquez (2003) of course acknowledges that organizations can be the bearer of properties that cannot be reduced to individual organizational members (538-541).

${ }^{4}$ Proposition 7 predicts that investments in CSP are likely to lead to greater effectiveness for moral communities relative to nexus-of-contracts and utilitarian organizations. The generalizability of this proposition is greater when investments have a positive opportunity cost, such that monies spent on legitimacy-enhancing activities like CSP 'cannibalize' on efficiency-enhancing activities like marketing and innovation. When there is no tradeoff, such that investments in CSP simultaneously make firms more efficient, the resulting legitimacy benefits for moral communities are less likely to result in strong effectiveness differentials vis-à-vis other organizational types. We thank JMS editor Steve Floyd for pointing this compensatory effect out to us.

5 "Happiness" is the stock translation of eudaimonia, but the two words are not perfect synonyms. The latter also encompasses connotations of "success" or "accomplishment," which are important for understanding the Aristotelian thesis as a whole and its applicability in the business context in particular. 


\section{Publications in the ERIM Report Series Research* in Management}

\section{ERIM Research Program: "Organizing for Performance"}

2007

Leadership Behaviour and Upward Feedback: Findings From a Longitudinal Intervention

Dirk van Dierendonck, Clare Haynes, Carol Borrill and Chris Stride

ERS-2007-003-ORG

http://hdl.handle.net/1765/8579

The Clean Development Mechanism: Institutionalizing New Power Relations

Bettina B.F. Wittneben

ERS-2007-004-ORG

http://hdl.handle.net/1765/8582

How Today's Consumers Perceive Tomorrow's Smart Products

Serge A. Rijsdijk and Erik Jan Hultink

ERS-2007-005-ORG

http://hdl.handle.net/1765/8984

Product Intelligence: Its Conceptualization, Measurement and Impact on Consumer Satisfaction

Serge A. Rijsdijk, Erik Jan Hultink and Adamantios Diamantopoulos

ERS-2007-006-ORG

http://hdl.handle.net/1765/8580

Testing the Strength of the Iron Cage: A Meta-Analysis of Neo-Institutional Theory

Pursey P.M.A.R. Heugens and Michel Lander

ERS-2007-007-ORG

http://hdl.handle.net/1765/8581

Export Orientation among New Ventures and Economic Growth

S. Jolanda A. Hessels and André van Stel

ERS-2007-008-ORG

http://hdl.handle.net/1765/8583

Allocation and Productivity of Time in New Ventures of Female and Male Entrepreneurs

Ingrid Verheul, Martin Carree and Roy Thurik

ERS-2007-009-ORG

http://hdl.handle.net/1765/8989

Cooperating if one's Goals are Collective-Based: Social Identification Effects in Social Dilemmas as a Function of Goal-Transformation David De Cremer, Daan van Knippenberg, Eric van Dijk and Esther van Leeuwen

ERS-2007-010-ORG

http://hdl.handle.net/1765/9041

Unfit to Learn? How Long View Organizations Adapt to Environmental Jolts

Pursey P. M. A. R. Heugens and Stelios C. Zyglidopoulos

ERS-2007-014-ORG

http://hdl.handle.net/1765/9404

Going, Going, Gone. Innovation and Exit in Manufacturing Firms

Elena Cefis and Orietta Marsili

ERS-2007-015-ORG 
High in the Hierarchy: How Vertical Location and Judgments of Leaders' Power are Interrelated Steffen R. Giessner and Thomas W. Schubert

ERS-2007-021-ORG

Contracts to Communities: a Processual Model of Organizational Virtue

Pursey P.M.A.R. Heugens, Muel Kaptein and J. van Oosterhout

ERS-2007-023-ORG

Why Are Some Entrepreneurs More Innovative Than Others?

Philipp Koellinger

ERS-2007-024-ORG

* A complete overview of the ERIM Report Series Research in Management: https://ep.eur.n//handle/1765/1

ERIM Research Programs:

LIS Business Processes, Logistics and Information Systems

ORG Organizing for Performance

MKT Marketing

F\&A Finance and Accounting

STR Strategy and Entrepreneurship 